\title{
Firm Size, Age, Leverage and Growth Opportunities: An initial inquiry by Pakistan
}

\author{
Shabbir Hussain \\ PHD Scholar, \\ National College of Business Administration and Economics, Lahore \\ Wasif Ali Waseer \\ Faculty, \\ National College of Business Administration and Economics, Lahore
}

\begin{abstract}
It is desired by all organizations to grow and sustain the factors of growth opportunities. This study is carried out to measure significant factors towards firm growth opportunities by using the data of Pakistani Firms. There were dissimilar results found in literature about selected variables with firm growth opportunities. This study is an attempt to support literature about significant factors towards growth opportunities by using the data of second largest Pakistan Industry (Sugar Sector). Pakistan Stock Exchange (PSX) listed firms have been observed as representative of overall sugar industry for the period of 1999-2015. Growth opportunities was observed with firm size, age, leverage, firm assets, industry sales, cash flows and market share by developing multiple linear regression model. It is found that growth opportunities for PSX listed firms are independent of its size, age and industry sales and all other explanatory variables are positively related with growth opportunities. This study supports literature that PSX listed firms show statistically significant and theoretically same results for all selected variables except firm size, age and industry sales.
\end{abstract}

\section{INTRODUCTION}

Conventionally, every business organization is formed to earn profits and it is of imperative importance that such organization has sustainable growth in the long run. This sustainable growth is not only desirable by the stockholders of the company. It is also desirable by stakeholders, regulators, financers, suppliers and customers on equally basis. Thus, it is of imperative importance to investigate the contributors of growth. In this scenario or background this study is carried out to observe contributing factor towards growth of the firm. In this way organization would be able to achieve prospects of its various stakeholders (GarciaPosada, M., \& Mora-Sanguinetti, J. S. 2015; Adelino, M., Ma, S., \& Robinson, D. 2017). In this regard, this study considers variables of firm profit, cash flows, market share, industry sales, owner's equity, leverage, firm's assets, firm's age and firm size as explanatory factors of growth opportunities.

Considering the importance of the growth, many researchers have tried to explain organizational growth during different times and for different types of organizations in different countries. This study picked all of its explanatory variables from literature or that have been used in the past studies, so that composite evidence could be provided to explain corporate growth in a developing economy of Pakistan. Sugar sector of Pakistan is chosen to investigate the phenomenon of growth and data is to be gathered from all sugar sector firms listed in Pakistan Stock Exchange, for the duration of 1999-2015. This study has dual purpose; firstly, it tries to establish significance of the existing literature by validating the findings of 
past studies. This will highlight the variables which have explanatory power for corporate growth, secondly; it provides practical implications for the corporate growth of the sugar sector firms in Pakistan.

Theory of growth relates organizational growth to the external opportunities and firm's ability of exploit these opportunities in an effective manner (Barney, 1986; Penrose, 1995; Coad, A., Segarra, A., \& Teruel, M. 2016). This study in this regard measures growth opportunities through the market to book ratio of the firm and relationship of various variables is sought in relation to it. Taking book to market value as proxy of growth is also relevant in the eyes of investors and stockholders (Navaretti, G. B., Castellani, D., \& Pieri, F. 2014). Thus, growth opportunities are measured in term of book to market value and its determinants are sought out in this study. Book to market value is taken as proxy of growth opportunities as it relates firm's invested internal value to its external real market value. May studies have recommended that book to market value is an appropriate proxy for measurement of the growth opportunities (Anderson, B. S., \& Eshima, Y. 2013; Chahine, Filatotchev, \& Piesse, 2007; LiPuma, J. A., Newbert, S. L., \& Doh, J. P. 2013; Ho, Tjahjapranata, \& Yap, 2006).

Theoretically, Gibrate's law tries to elaborate phenomenon of firm's growth and observed that firm growth is independent with size of firm (Hart, 1962; Hart \& Oulton, 1996; Loderer, C., Stulz, R., \& Waelchli, U. 2016). While other studies found quite interesting results in this regard; some studies have rejected Gibrate's law as these studies found a negative impact of size on the growth opportunities (Bernard, A. B., Massari, R., Reyes, J. D., \& Taglioni, D. 2014).

On the other hand, researches like Hermelo and Vassolo (2007) and Anton, S. G. (2016) supported the law on account of evidence of insignificant relationship between size and growth opportunities. Thus, difference of opinion exists on the determinants of growth opportunities in corporate sector.

Determination of the growth has been an important area in the business research and a lot of studies have investigated the phenomenon. But, studies conducted so far provide conflicting results in this regard and this conflict persists for different industries, time periods and countries. The excessive of evidence in this regard implies that growth nexus should be investigated for a specific industry and with reference to a specific market in order to draw specific and relevant implications.

This study in this regard includes all the important variables for the determination of growth in order to provide a comprehensive evidence of growth determination. Therefore, this study not only provides a comprehensive evidence on determination of firm's growth; but also contributes to the body of the literature and provides an evidence with reference to a developing country i.e. Pakistan.

Further, Raheman, Qayyum, and Afza (2014) indicated that sugar sector is a viable sector of Pakistani industry and crises in sugar industry due to sugar shortage implies that growth of the sector is much needed. Thus, determination of the factors that contribute towards the growth of the sector are of imperative importance. Further, most of the work on the determination of growth is concentrated on the developed countries, and developing nations have received less attention in this regard. Therefore, this study is expected to bridge this gap and provide implications for sugar sector of a developing economy. 


\section{LITERATURE REVIEW}

This section is consisting of various studies on same or similar variables at different time periods. Various book reviews, research articles, case studies were conducted independently of each other. In such a way that one manuscript was reviewed in one sitting over the course of time. Forthcoming review was written after thorough study and securitization of available published content. This literature denoted existing wisdom on the variable of study at hand. Other variable which were not included in this study but has shown to have direct or indirect impact on the study variables were also looked upon.

Firm growth has been studied extensively over the course of past two decades. Other variables have been shown to have relationship with Firm Growth. The purpose of literature is to identify some variable important and consistent to study with said variable of current study. Firm Size and Firm Age are among those common variables that are used in previous research to correlate with firm growth (Peric, M., \& Vitezic, V. 2016; Callen, J. L., \& Chy, M. 2016). The current study at hand is based on Gibrat law, according to which the Firm Size is independent to Firm growth (Hart, 1962). Jovanovic theory presents a different perspective with respect to studying firm growth. According to this theory, smaller firms grow faster. In other words, Firm Age is inversely related to firm growth (Jovanovic, 1982). Later on, one can find many other studies analyzing the relationship of these two variables with firm growth but it is evident that results of those studies are fairly consistent with what has already been posited in previous sentences (Ayyagari, M., Demirguc-Kunt, A., \& Maksimovic, V. 2016).

In layman terms, growth means the process of growing or increasing as compared to previous time horizon. However, according to classical theory, growth can be measured by recording change (discounted) in cash flow profits (Arkolakis, C., Papageorgiou, T., \& Timoshenko, 0. A. 2017). On the other hand, absolute and proportionate perspectives can be employed to measure the Change (Faulkender, M., \& Smith, J. M. 2016). Different perspective is adopted for different purposes. According to classical model, "Firms are organizations which maximize wealth and are competitive or monopolistic or oligopolistic in nature" (Cressy, 2006).

Growth can also be viewed as a consequence of exploring imminent opportunities (Abdullah, N. A. I. N., Ali, M. M., \& Haron, N. H. 2017). Firm growth is stemmed from an active and ingenious interaction between productive resources of a firm and opportunities presented by market. Growth of a firm can not be put to limits, however, the "rate of growth" the actual variable that is limited in short term and, size of a firm also is not limited (Penrose, 2009).

A comprehensive study was conducted with the aim of measuring growth opportunities of companies in developed countries. R \& D expenditures, time trend, age, leverage, sales and industry effects were used as independent variables in order to measure growth. This study also measured growth by Market to Book Ratio. Ratio of Total Debt to Equity was employed as proxy for Leverage. Finally, as proxy for Time Trend, Economic Changes were studied (Li, L., \& Kuo, C. S. 2017).

Other studies were also conducted by Mira Tjahjapranata, Yew Kee Ho and Chee Meng Yap in 2006. Growth opportunities were observed with firm assets, financial leverage, industry sales and R \& D expenses. In these studies, ratio of Market to Book Value was used as proxy of growth opportunities. Natural logarithm of Net Sales was used to measure Firm size. The same was employed as a proxy for Financial Leverage (the ratio of Long Term Debt to Book Value of Total Assets at end of year). As in previous studies, regression analysis was used to compute result. They denote that Research and Development Investment has positive influence on Company Growth Opportunities. This relationship is magnified by Firm Size (when it is large), 
but diluted by High Industry Concentration. Another study also suggested that Financial Leverage, Firm Size and Industry Concentration relationship showed advantages of Firm Size. This relationship was moderated by Financial Leverage (Adelino, M., Ma, S., \& Robinson, D. 2017).

Francisco Diaz Hermelo and Roberto Vassolo postulated about the determinants of growth of company of Tucumun Argentina. This study was conducted in 2007 with an Objective to measure growth of firms in emerging economies. Records of small and medium size companies were used. Other variables of consideration were; Average Return on Sales, Firm Size, Financial Resources, Diversification or Access to International Markets and Technology. These were used to determine Firm Growth. Sales were used as determine of Growth. Financial resources were denoted by profits. According to the results, the effect of Size was inconsistent with Gilbert Model. Similarly, Average Return on Sales is positive related to Growth and this relation was significant. Companies having larger Financial Funds demonstrated high Returns from Retained Earnings. It was also evident from external financing to provide for upcoming projects, invest in new technology and to be able to attain growth (Hermelo \& Vassolo, 2007).

Several studies have empirically provided evidence that market share and growth of the firm has positive relationship (Kleinknecht, 1996) and (Cohen, 2010). In support of this studies (Wijewardena \& Tibbits, 1999) concluded by using multi regression model that growth of firm has negative relationship with firm age. In literature many studies investigate some other factors such as information asymmetry and agency cost have postively related with firm growth. Stein (2003) argued that agency cost and information asymmetry has significant impact on the firm growth and firm investment. Firms can easily decrease their cost of financing and can increase their potential growth opportunities (Stein, 2003) (Verrecchia, 2001), (Khurana, Pereira, \& Martin, 2006).

In order to support this phenomena another study was conducted in Morocco by the World Bank in 1998 through field survey of 370 firms. Size of the firms (5-100 workers) and different economic sectors were used as sample, the study provided that firm age and firm size has negative relationship with firm growth while market demand and market share has significant positive relationship with firm growth (Eshima, Y., \& Anderson, B. S. 2017; Harabi, 2005).

(Lang, Ofek, and Stulz, 1994; Kang, T., Lobo, G. J., \& Wolfe, M. C. 2017) exercised a study to know the reltionship of firm growth, investment, leverage and cash flows, this study suggested that this relationship is pervails in the inustries and leverage directly affects the firm growth, cash flows has postive impact on firm growth and has no relationship with the companys' investment. Another study revealed many factors with has direct relatioshop with firm growth, four major factors were suggested by the author such as contextual facotors(organizationa environment), entrepreneurial characteristics, relationlal factors and firm chracteristics, after studying extensive available literature on this field they concluded that business environment, internal cooperation in the firm, education, experience and ease availablity of finacial resource are positive related to firm growth and location, age and gender have inverse realtionship with firm growth(Nichter \& Goldmark, 2009).

Gracia \& Mira (2008) describe that there is significant positive relationship between the leverage and firm growth. Furthermore it was measured that in short run growth is dependent while in long run it depends on the structure of assets, and firms who specifically invest in tangible assets are generally financed by the external factors. (Brierley, 2001). 
Davidsson, Kirchhoff, Hatemi-J, and Gustavsson, 2002, investigated a study in Sweden to measure the factors which contribute signinficantly to growth by considering industrial sector, age and size as a independent variable and by applying regression model this study provide empirical evidence that firm age in inversely related to firm growh, size is negatively related to firm growth.

Chiarella, Pham, Sim, and Tan, 1991 undertake a research study to investigate the relationship of profitability, tax shields, firm size and growth opportunities for the leverage of firms, this study concluded that leverage, firm size, cash flows and growth opportunities are significantly and positively related to each other while firm leverage, tax shields and profitability are negatively related to each others.

Mira (2005) measured the relationship profitability, firm growth, tax shields, firm size and leverage used by the firms, this study was conducted on 6482 non-financial small and medium enterprises of Spain by using Penal Data from the period of 1994-1998. The result of this study observed that tax shields and profitability are inversely related with leverage of the firm while firm size, growth and asset structure are directly related to leverage.

Beck, Kunt, and Maksimovic, 2005 investigated a study on 4000 firms from 54 different countries to understand the impact of financial, legal, and corruption obstacles on the growth of companies. The study cosisted of the the questions about financial ,legal , number of employees, sales, growth and corruption issues, all these varialbles greatly affect the growth fo the firm but this all of them are not equally signinficant for all the firms in the industry, small and medium enterprises showed major impacts while large scale firms were not greatly affected by these factors.

Moon and Tandon (2007) summarized the relationship between variation in leverage, equity structure, and growth opportunities, this study measured that equity structure and leverage has strong association for the firms which have few growth opportunities, and weak association for the firms which have larger growth opportunities.

Farinas and Moreno, 2000 promulgated a study to investigate the factors which significanlty contribute to growh by using model of Jovanovic to frame the study, penal data was collected from Spanish firms in accordance with their size and categories from the period of 1990 to 1995 , the study empirically measured that there is no relationship in the average growth rate along with the age and size of the firms, rate of failure decreases with the age and size of firm and average growth rate of highly competitive firms reduces with the age and size of the firms.

In addition to this another research study was undertaken to calculate the association between productivity, growth, firm size and profitability on the African manufacturing firms, the study observed that firms which have hundred or more then hundred employees are productive firms and their survival rate is higher, and larger firms grow quickly and their relationship between productivity and firm size is low (Eshima, Y., \& Anderson, B. S. 2017).

Another study used price earnings ratio as growth and developed global industry portfolio for finding out major determinants to growth. This study derived three important results; firstly, growth opportunities strongly predict investment opportunities and gross domestic product at country level. Secondly, this study predicts positive relationship between capital attraction, financial development and growth opportunities. Thirdly, this study observed that growth is significant with relative share at country level but less significant with global portfolio (Bekaert, Harvey, Lundblad, \& Siegel, 2007). 
Shin and Stulz (2000) measured the relationship between firm risk and growth. Tobin's q ratio is used as proxy of growth. This study conluded that growth opportunites fall with un-systatic risk and increase with systematic risk. The overall all equity risk is negatively associated with book to market ratio. Further, this negative relationship is strong for small level firms and less strong for larg firms.

Eberhart, R. N., Eesley, C. E., \& Eisenhardt, K. M. (2017) coducted study to measre relationship between growth and cash flows available to firm. Sample data was collected on random sampling through compustat database for the period of ten years. This study firstly divided the study into two groups of having free cash flow with strong governance and firms having free cash flows with weaker governance. This study showed positive association of firm growth with industry sales, firm profitability, industry profitability, industry sales, capital market returns. This relationship is strongly significant in firms having strong governance and cash flows than firms having lack of governance.

Another study was conducted to observe growth with firm assets, profitability, market risk and leverage by using large sample data. This study used the data of different countries and also conducted comparison between selected companies of different countries. Growth is measured with market to total capital employed ratio and concluded that in all countries profitablity is significantly corelated with firm growth. Furthermore, assets are more significant in USA, Norway, Holland but not in France. Debt ratio is positivily significant with risk in USA, France and Norway but not in Holand; it means growth is negatively associated in USA, France, Norway and positivily in Holand (Hosono, K., Takizawa, M., \& Tsuru, K. 2017).

\section{THEORETICAL FRAMEWORK}

Firm growth can be measured through different ways; through comparison of sales in any firm and if there is growth in sales, it indicates about the growth of the firm. Furthermore, if there is growth in firm assets or total volume of assets increased as compared to previous then it indicate about the growth of the firm. Similarly comparison of its profits, its market share, its production level or opportunities to grow reveals that all these factors or any one of this factor is growing; then it indicates that the respective firm is growing. The afore stated all variables have been viewed by different researchers in literature to measure growth in different time spans.

This study used the methodology of Reilly \& Brown (2005), Chahine et al. (2007), Ho et al. (2006), Kallapur \& Trombley (1999), Barney (1991), Penrose E. T. (1995), Loderer et al. (2016) and Anton, S. G. (2016) to measure about the relationship of significant factors with firm growth. These researchers considered 'growth opportunities available' to firm as growth. They uses book to market ratio to measure growth opportunities and show that higher the book to market ratio means the firm is growing.

This study also used book to market ratio as growth opportunities available to firm and growth opportunities available to firm considered as growth of the firm. The following diagram indicates the all explanatory variables observed by this study to find out more important factors with growth of the firm. 


\section{Floral Diagram 1}

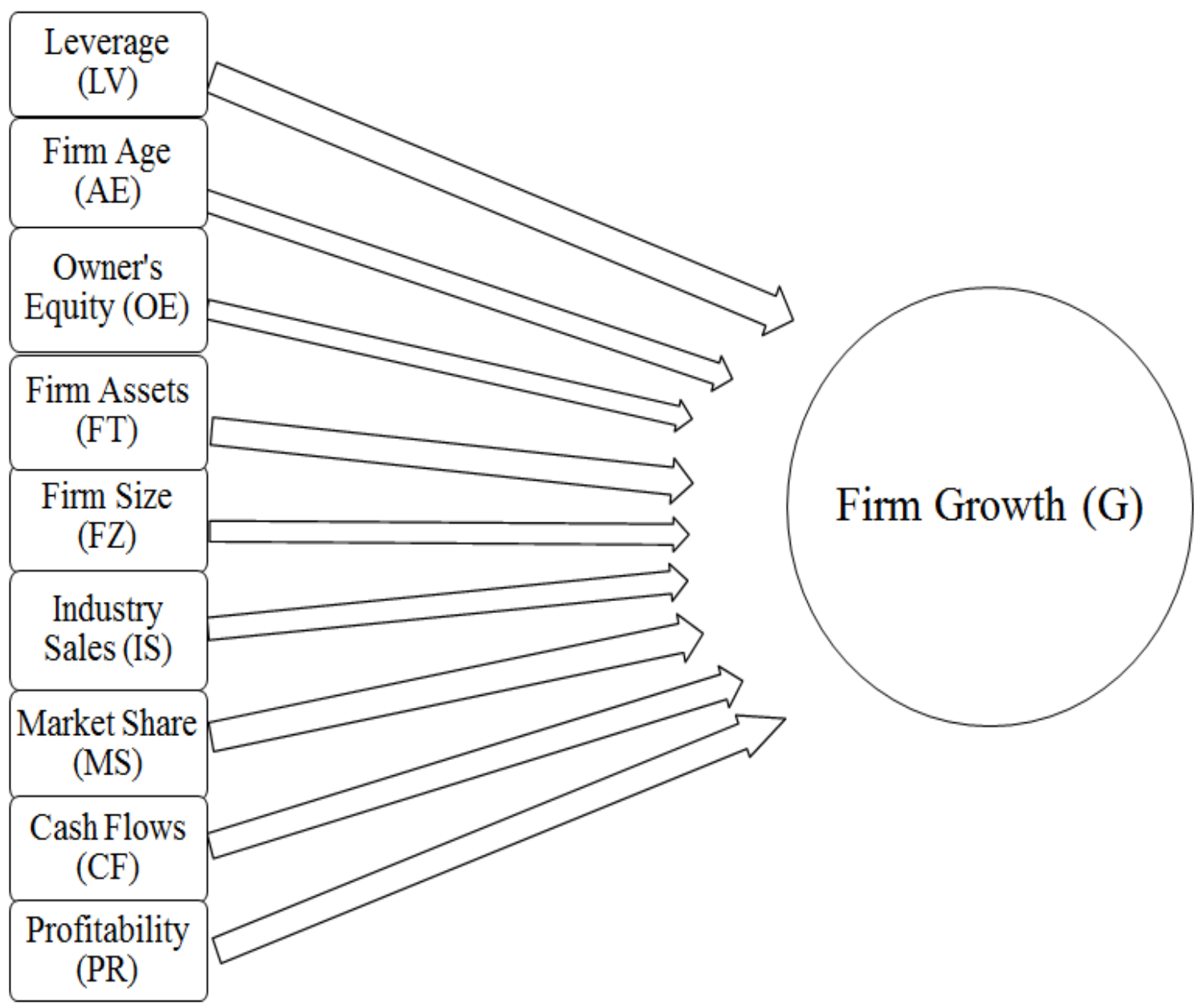

The first variable in this model is Leverage and this study assumed negative association of firm leverage with firm growth. The leverage of the firm can be calculated as debt to equity ratio, means higher debt to equity ratio will indicate lower portion of owner's equity. Similarly, lower amount of owner's equity will result in lower book value and lower book value shows low book to market ratio. Therefore, one can theorize that leverage is negatively associated with firm growth opportunities. Ho et al (2006), Chiarella et al. (1991), and Johnson (2003) also found the negative association between leverage and firm growth.

Firm Age is life of company from its incorporation date and measured in number of years. This study theorizes positive relationship between firm age and growth as firm get older it will learn from market experiences and can perform better as compared to newly born firms in any industry. Therefore this study assumes positive association between firm growth and its age. On the contrary part Ericson \& Pakes (1995) found negative association between these variables.

Owner's equity is exactly same as book value of firm shown in the books of accounts. Therefore the firm having higher owner's equity or book value it will directly lead to higher book to market ratio. However one can assume positive relationship between owner's equity and market to book ratio or growth opportunities. There is also found positive relationship between Owner's equity and growth opportunities (Denis, 1994). 
Firm sales are used as proxy firm size and this study assumed positive association between growth opportunities and firm growth. Sales volume leads to profits and profits retained by business ultimately transferred to owner's equity. So, if there is higher owner's equity then there will be higher book to market ratio or growth opportunities. Farinas \& Moreno (2000) and Epstein (1934) found positive association between these two variables.

This study also assumed positive relationship between firm assets and growth. Assets held by the company are calculated as total fixed assets (plant property and equipment). If liabilities remain constant then increase in assets will increase owner's equity. Consequently, owner's equity will impact positively on growth opportunities. Mira (2005) Baumol et al. (1970) and Harris (1994) showed positive association with growth.

Industry sales can be computed as summation of sales of whole industry. This study supposed that there is a direct relationship between firm's growth and industry sale. Because industry sales means the sale of all the firms which are part of that industry, if industry sales increase that means the sales of individual firms increase. Increments in the individual sales of the firm will positive change in book value and firm growth. According to the Sharma and Kasner (1996), there is a direct relation between firm growth and growth of the industry. Marcus (1969) also explains the cause and effect relation between firm growth and firm sales and revealed that firm's growth has positive and significant impact on firm's growth.

Next explanatory variable of the study is Market share, which can be defined as the ratio of individual company share from overall industry. This study supposed that there is a direct relation between firm growth and market share. Because if a single company have a greater market share than other company that means that company contribute more than other companies in overall sale. More contribution in sales indicates that that company have greater profit ratio than other. Several past studies revealed the direct relation among the firm's growth and market share (Kleinknecht, 1996) (Cohen, 2010) (Harabi, 2005).

Next variable which is taken as independent variable is free cash flows of the firm. This study purposed that there is a direct relation between growth of the firm and cash flows of the firm. Positive relation revealed that free cash flows of the firms shown as reserves of that firms and it indicates that increment of the firms' owners' equity. Higher the owners' equity means, there are more opportunity for investment which indicate the firms growth. Some past studies also show such type of relation between said variables means free cash flows and firms growth (Brush, Bromiley, \& Hendrickx, 2000) (Chiarella, Pham, Sim, \& Tan, 1991).

Last variable is profitability of the firm which also refers as net profit of the firm. Again this study purposed direct association among profits and firms' growth. Profits also have positive impact on book value and common stock equity which reveals growth of the firm. Prior studies also explain this relation (Marcus, 1969; Epstein, 1934; Harris, 1994).

\section{METHODOLOGY AND RESEARCH DESIGN}

This part of study analyzes the data with the help of source of data collection, population, sample size, methodology, estimation technique for examine the relationship between explained and explanatory variables and model formation.

\section{Population and Sample size}

There are 86 sugar companies working all over Pakistan. There are forty six companies listed at PSX by 2015. This study selected all forty six companies for data analysis as it will be 
representative to the population and therefore it will be easy to generalize the result of this study to total universe/population.

\section{Data source}

This study analyzes by applying secondary source, annual reports of the respective companies are used for this purpose. To find out the missing values this study used another report that is published by State Bank of Pakistan with the name of "analysis of joint stock companies". The market Value is determined through market price from business recorder and PSX historical data. Market value of every company shares is picked at the end of September month of every year because the financial year for sugar companies in Pakistan is 01-August till 30-September.

\section{Dependent Variable - Growth opportunities}

We found from many studies that Growth is a continuous process of growing. There are number of measures used for calculation of growth of firms. Many researchers calculate it by taking the value of change in sales (Brush, Bromiley, \& Hendrickx, 2000). Some studies measured growth by taking change in size. It can also be measured through change in profitability value.

(Barney J. B., 1986) and (Penrose E. T., 1995) reported that Growth is taken as an opportunity of future growth in companies or return on investment in future. It can also be defined as growth is helpful measure to detect future opportunities. Chahine et al. (2007), Ho et al. (2006) used Book to Market ratio as ex ante for company returns. Therefore, it is used in this study to determine company returns. (Kallapur \& Trombley, 1999) also found that Book to Market ratio is determined as benchmark for investment opportunities. In addition, Reilly \& Brown (2005) analyzed that Book to Market ratio has significant positive impact on growth of company. Hence, book to market ratio and future opportunities can be considered as measures of growth.

\section{Independent Variables}

Firm size can be measured through different measures such as number of employees working in a firm, asset size or sales of firm. Data regarding no. of employees was not available for all firms of sugar industry in Pakistan. That's why, Firm sales is taken as proxy for Firm size. This study used firm sales as proxy of firm size and is also found in literature that firm size take firm sales as proxy variable (Hermelo \& Vassolo, 2007), the Size can be measured by Assets or Sales of the firm (Ijiri \& Simon, 1967). For this purpose, sales amount is carried out from annual reports of sugar firms.

Owner's equity is defined as value of capital sum up of three different types of capital i.e. issued capital, subscribed capital and paid-up capital. In this study, owner's equity is taken as proxy of common stock equity. It is calculated by addition of ordinary share capital, retained earnings and reserves.

Age can be defined as life of company is calculated in number of years from the establishment of firm to recent year. For example if a company was established in 1995 then its age as on 2015 is 20 years.

Fixed assets can be defined as property, plant and machinery in possession of a firm. It is measured as fixed assets at cost minus depreciation and adds any long term investment made by firms. 
Long term debt is considered as leverage of firm due to longer time period impact. Leverage can be defined as the ratio of long term debt to equity. (Chahine, Filatotchev, \& Piesse, 2007) found this that leverage can be measured by dividing long term debt to equity of firm. Industry Sales can be defined as total sales of Sugar Industry. It is calculated by adding sales of total sugar companies in the respective financial year.

Market Share can be defined as the share of single Company in Overall Industry. It is measured by dividing Individual Firm's sales to Industry Sales.

Free cash flow available to firm in one accounting year is considered as cash flows of respective firm. Cash Flow statement is used and cash retained in business after three activities (operating, financing, and investing) is the cash flows considered in this study.

Value of Profitability can be defined as net profit of firm taken from the respective financial year from balance sheet of firm.

\section{RESULTS AND ANALYSIS}

Table 1

Regression Analysis

\begin{tabular}{crrrr}
\hline Variable & Coefficient & Std. Error & t-Statistic & Prob. \\
\hline F & 0.39663 & 1.826126 & 0.17443 & 0.8616 \\
FT & 0.00138 & 0.000411 & 0.18477 & 0.7472 \\
FE & $5.241307^{*}$ & 0.000370 & 2.02197 & 0.0703 \\
AE & $3.928173^{*}$ & 21.64270 & 2.17379 & 0.0557 \\
LV & $0.088651^{* * *}$ & 0.002367 & 29.1143 & 0.0000 \\
IS & 1.05270 & 0.000139 & 0.71656 & 0.7907 \\
MS & $1.2532^{*}$ & 21.02500 & 3.00021 & 0.0595 \\
CF & $4.980157^{*}$ & 0.001289 & 2.02932 & 0.0673 \\
PR & $0.001803^{*}$ & 0.001735 & 2.12069 & 0.0697 \\
\hline
\end{tabular}

*e-views software results.

$*, * *$ and ${ }^{* * *}$ represents significance at the $0.10,0.05$, and 0.01 levels, respectively. 
Table 2

\begin{tabular}{lrll}
\hline R-squared & 0.781704 & Mean dependent var & 0.043786 \\
Adjusted R-squared & 0.753209 & S.D. dependent var & 5.167533 \\
S.E. of regression & 2.510761 & Akaike info criterion & 4.678951 \\
Sum squared resid & 1981.231 & Schwarz criterion & 5.190427 \\
Log likelihood & -798.4051 & Hannan-Quinn criter. & 4.784304 \\
F-statistic & 29.65803 & Durbin-Watson stat & 1.835208 \\
Prob(F-statistic) & 0.000000 & & \\
\hline
\end{tabular}

*e-views software results.

$*, * *$ and ${ }^{* * *}$ represents significance at the $0.10,0.05$, and 0.01 levels, respectively.

Table 3

Correlations among Explanatory Variables

\begin{tabular}{lrrrrrrrrr}
\hline & \multicolumn{1}{c}{ FZ } & FT & OE & AE & LV & IS & MS & CF & PR \\
\cline { 2 - 10 } FZ & 1 & & & & & & & & \\
FT & $.268^{* *}$ & 1 & & & & & & & \\
OE & $.369^{* *}$ & $.559^{* *}$ & 1 & & & & & & \\
AE & .031 & .020 & .037 & 1 & & & & & \\
LV & .034 & .038 & .059 & .019 & 1 & & & & \\
IS & $.460^{* *}$ & $.302^{* *}$ & $.268^{* *}$ & $.195^{* *}$ & -.039 & 1 & & & \\
MS & $.316^{* *}$ & $.470^{* *}$ & $.396^{* *}$ & -.037 & .061 & .003 & & & \\
CF & $.007^{* *}$ & $.318^{* *}$ & $.449^{* *}$ & -.080 & .041 & $.239^{* *}$ & $.378^{* *}$ & 1 & \\
PR & $.417^{* *}$ & .025 & $.321^{* *}$ & -.051 & .070 & $.143^{*}$ & $.337^{* *}$ & $.801^{* *}$ & 1 \\
\hline
\end{tabular}

$*, * *$ and ${ }^{* * *}$ represents significance at the $0.10,0.05$, and 0.01 levels, respectively.

Table 1 and 2 provides estimation results of the regression where growth opportunities was dependent variable and firm size, firm assets, owner's equity, firm age, leverage, industry sales, market share, cash flows and profitability were independent variables. R-square of the model was $78.17 \%$ indicating that the model has good explanatory power. Further, F-statistics of the model was 29.65 indicative of goodness of fit of model at $1 \%$ level of significance.

The first independent variable was firm size (FZ) which had a positive but insignificant impact on the growth opportunities. The second variable was firm's assets (FT) which had a positive and mildly significant $(\mathrm{p}<.1$ ) impact on the growth opportunities. Owner's equity (OE) also had a mildly significant and positive impact on the growth opportunities. Fourth independent variable of firm's age (AE) had a positive but insignificant impact on growth opportunities. Next independent variable i.e. leverage (LV) had a positive and significant $(p<.01)$ impact on the growth opportunities. Next independent variable of industry sales (IS) had insignificant impact on the growth opportunities. Market share (MS) on the other hand had a positive and mildly significant $(\mathrm{p}<.1)$ impact on the growth opportunities. Same is the case of cash flows (CF) and profitability (PR). Both variables had a positive and mildly significant impact on the growth opportunities of the firms in the sugar sector of Pakistan.

Overall, leverage was found to be most important determinant of growth opportunities in the sugar sector of Pakistan. Other variables like firm's assets, owner's equity, market share, cash flows, and profitability had a mildly significant and positive impact on the growth opportunities of the firms. 
Table 3 provides correlation analysis for the variables included in the study, the analysis was conducted to assess the extent of multicollinearity between the independent variables of the study. No variable had a strong correlation with other variable as all the coefficients are below the threshold value of .8. Thus, there was no multicollinearity between independent variables of the study.

\section{CONCLUSION}

Sugar sector is one of the most important corporate sector in the Pakistani economy and there are much growth opportunities present in the sector as indicated by the sugar shortages in the country. This study I this regard tried to determine the factors that are associated with the growth of the sugar sector firms. The study found that leverage was most important factor associated with the growth opportunities and other important factors included firm's assets, owner's opportunities, market share, cash flows and profitability. All of these variables are associated with the financing strength of the company. So, firms who have excess debt capacity and could arrange both internal and external finances could grow much more easily in the sector. Thus, it is recommended that firms should avoid paying the dividends to the shareholders and invest more to avail growth opportunities. Further, firms should improve their financial strength, profitability and cash flows to have better access to capital markets, which is an important credential for the growth in the industry.

\section{References}

Abdullah, N. A. I. N., Ali, M. M., \& Haron, N. H. (2017). Ownership Structure, Firm Value and Growth Opportunities: Malaysian Evidence. Advanced Science Letters, 23(8), 7378-7382.

Acs, Z. J., \& Isberg, S. C. (1991). Innovation, firm size and corporate fnance: An initial inquiry. Economics Letters , 323-326.

Adelino, M., Ma, S., \& Robinson, D. (2017). Firm age, investment opportunities, and job creation. The Journal of Finance.

Almus, M., \& Nerlinger, E. A. (1999). Growth of new technology-based firms: Which factors matter. Small Business Economics , 13, 141-154.

Anderson, B. S., \& Eshima, Y. (2013). The influence of firm age and intangible resources on the relationship between entrepreneurial orientation and firm growth among Japanese SMEs. Journal of Business Venturing, 28(3), 413-429.

Anton, S. G. (2016). The Impact of Leverage on Firm Growth. Empirical Evidence from Romanian Listed Firms. Review of Economic and Business Studies, 9(2), 147-158.

Anwar, D. M. (2005). Research methods (2005 edition ed., Vol. 2). Lahore: Virtual University of Pakistan.

Arkolakis, C., Papageorgiou, T., \& Timoshenko, O. A. (2017). Firm learning and growth. Review of Economic Dynamics.

Ayyagari, M., Demirguc-Kunt, A., \& Maksimovic, V. (2016). INSTITUTIONS, FIRM FINANCING, AND GROWTH. Barney, J. B. (1991). Firm Resources and Sustained Competitive Advantage. Journal of Management, 17 (1), 99 120.

Baumol, W. J., Heim, P., Malkiel, B. G., \& Quandt, R. E. (1970). Earnings retention, new capital and the growth of the firm. The Review of Economics and Statistics , 52 (4), 345-355.

Beck, T., Kunt, A. D., \& Maksimovic, V. (2005). Financial and legal constraints to growth: Does firm size matter? The Journal of Finance, 60 (1), 137-177.

Bekaert, G., Harvey, C. R., Lundblad, C., \& Siegel, S. (2007). Global growth opportunities and market integration. Journal of Finance, 62 (3), 1081-1137.

Bernard, A. B., Massari, R., Reyes, J. D., \& Taglioni, D. (2014). Exporter dynamics, firm size and growth, and partial year effects (No. w19865). National Bureau of Economic Research.

Biesebroeck, J. V. (2005). Firm size matters: Growth and productivity growth in African manufacturing firms. Economic Development and Cultural Change , 53 (3), 545-583. 
Billett, M. T., King, T.-H. D., \& Mauer, D. C. (2007). Growth Opportunities and the choice of leverage, debt maturity and covenanats. The Journal of Finance , 62 (2), 697-730.

Brierley, P. (2001). The financing of Technology based small firms: A review of the literature. Bank of England.

Brush, T. H., Bromiley, P., \& Hendrickx, M. (2000). The free cash flow hypothesis for sales growth and firm performance. Strategic Management Journal , 21 (4), 455-472.

Callen, J. L., \& Chy, M. (2016). Growth Opportunities, Leverage and Financial Contracting: Evidence from Exogenous Shocks to Public Spending.

Chahine, S., Filatotchev, I., \& Piesse, J. (2007). The Effects of R \& D Investment and Firm Size on Growth Opportunities of Newly Listed Firms: European Evidence. European Finance Association Confernce, (pp. 56-78). Slovenia.

Chan, L. K., Lakonishok, J., \& Sougiannis, T. (2001). The stock market valucation of research and development expenditures. The Jounal of Finance , 6, 2431-2456.

Choe, H., Masulis, R., \& Nanda, V. (1993). On the timing of seasoned common stock issues: Theory and evidence. Journal of Empirical Finance, 1, 3-32.

Clark, K. B. (1984). Unionization and firm performance: The impact on profits, growth, and productivity. The American Economic Review , 74 (5), 893-919.

Coad, A., Segarra, A., \& Teruel, M. (2016). Innovation and firm growth: Does firm age play a role?. Research Policy, 45(2), 387-400.

Cohen, W. M. (2010). Handbook of the Economics of Innovation (2 ed.). (B. H. Hall, \& N. Rosenber, Eds.) University of California.

Cressy, R. (2006). Determinants of small firm survival and growth. (Casson, Ed.) Oxford Handbook of Entrepreneurship , 67-84.

Davidsson, P., Kirchhoff, B., Hatemi-J, A., \& Gustavsson, H. (2002). Empirical analysis of growth factors using Swedish data. Journal of Small Business Management, 40 (4), 332-349.

Denis, D. J. (1994). Investment opportunities and the market reaction to equity offerings. The Journal of Financial and Quantitative Analysis , 29 (2), 159-177.

Eberhart, R. N., Eesley, C. E., \& Eisenhardt, K. M. (2017). Failure is an option: Institutional change, entrepreneurial risk, and new firm growth. Organization Science, 28(1), 93-112.

Epstein, R. C. (1934). Industrial profits in the United States. New York: National Bureau of Economic Research.

Ericson, R., \& Pakes, A. (1995). Markov perfect industry dynamics: A framework for empirical work. The Review of Economic Studies , 62 (1), 53-82.

Eshima, Y., \& Anderson, B. S. (2017). Firm growth, adaptive capability, and entrepreneurial orientation. Strategic Management Journal, 38(3), 770-779.

Evans, D. S. (1987). The relationship between firm growth, size and age: Estimates for 100 manufacturing industries. The Journal of Industrial Economics , 35 (4), 567-581.

Farinas, J. C., \& Moreno, L. (2000). Firm growth, size and age: A non parametric approach. Review of Industrial Organizations , 17, 249-265.

Faulkender, M., \& Smith, J. M. (2016). Taxes and leverage at multinational corporations. Journal of Financial Economics, 122(1), 1-20.

García-Posada, M., \& Mora-Sanguinetti, J. S. (2015). Does (average) size matter? Court enforcement, business demography and firm growth. Small Business Economics, 44(3), 639-669.

Gibrat, R. (1931). Behavior of firm growth with firm size . Les Inegalites Economiques , 52-67.

Gracia, J. L., \& Mira, F. S. (2008). Testing trade-off and pecking order theories financing SMEs. Small Business Economics , 31 (2), 117-136.

Gujrati, D. N., \& Porter, D. (2009). Essentials of econometrics (4 ed.). United States: Mcgraw Hill.

Harabi, N. (2005). Determinants of firm growth: An empirical analysis from Morocco. Munich Personal Repec Archive(MPRA) , Paper No 4394. 
Hardwick, P., \& Adams, M. (2002). Firm size and firm growth in the United Kingdom Life Insurance Industry. The Journal of Risk and Insurance , 69 (4), 577-593.

Harris, F. H. (1994). Asset specificity, capital intensity and capital structure: An empirical test. Managerial and Decision Economics , 15 (6), 563-576.

Hart, P. E., \& Oulton, N. (1996). Growth and size of firms. The Economic jounral, 106 (438), 1442-1252.

Hart. (1962). The size and growth of firms. Economica, New series , 29 (113), 29-39.

Hermelo, F. D., \& Vassolo, R. (2007). The determinants of firm's growth: An empirical examination. Revista Abante , 10 (1), 3-20.

Ho, Y. K., Tjahjapranata, M., \& Yap, C. M. (2006). Size, leverage, concentration and R \& D investment in generating growth opportunities. The Journal of Business, 79 (2), 851-876.

Hosono, K., Takizawa, M., \& Tsuru, K. (2017). Size-dependent Policy and Firm Growth. Research Institute of Economy, Trade and Industry (RIETI).

Johnson, S. A. (2003). Debt maturity and the effects of growth opportunities and liquidity risk on leverage. Review of Financial Studies, 16 (1), 209-236.

Jovanovic, B. (1982). Selection and the evolution of industry. Econometrica , 50 (3), 649-670.

Kallapur, S., \& Trombley, M. A. (1999). The association between investment opportunity set proxies and realized growth. Journal of Business Finance and Accounting , 26 (3-4), 505-519.

Kang, T., Lobo, G. J., \& Wolfe, M. C. (2017). Accounting conservatism and firm growth financed by external debt: The role of Debt Maturity. Journal of Accounting, Auditing \& Finance, 32(2), 182-208.

Khurana, I. K., Pereira, R., \& Martin, X. (2006). Firm growth and disclosure: An empirical analysis. The Journal of Financial and Quantitative Analysis , 41 (2), 357-380.

L., Ofek, E., \& Stulz, R. M. (1994, Apri). Leverage, investment and firm growth. NYU Working Paper Number Fin-94041 .

Li, L., \& Kuo, C. S. (2017). CEO equity compensation and earnings management: The role of growth opportunities. Finance Research Letters, 20, 289-295.

LiPuma, J. A., Newbert, S. L., \& Doh, J. P. (2013). The effect of institutional quality on firm export performance in emerging economies: a contingency model of firm age and size. Small Business Economics, 40(4), 817-841.

Loderer, C., Stulz, R., \& Waelchli, U. (2016). Firm Rigidities and the Decline in Growth Opportunities. Management Science.

Mansfield, E. (1962). Entry, Gibrat's law, innovation, and the growth of firms. The American Economic Review, 52 (5), 1023-1051.

Marcus, M. (1969). A note on the determinants of the growth of firms and Gilbrat's law. The Candian Jouran of Economics , 2 (4), 580-589.

Mira, F. S. (2005). How SME uniqueness affects capital structure: Evidence from a 1994-1998 Spanish panel data. Small Business Economics , 25 (5), 447-457.

Modigliani, F., \& Miller, M. (1958). The cost of capital, corporation finance and the theory of investment. The American Economic Review , 48, 261-297.

Moon, D., \& Tandon, K. (2007). The influence of growth opportunities on the relationship between equity ownership and leverage. Review of Quantitative Finance and Accounting , 29 (4), 339-351.

Navaretti, G. B., Castellani, D., \& Pieri, F. (2014). Age and firm growth: evidence from three European countries. Small Business Economics, 43(4), 823-837.

Nichter, S., \& Goldmark, L. (2009). Small firm growth in developing countries. World Development, 37 (9), 1453 1464.

Parker, J. E. (1964). Profitability and growth of British industrial firms. The Manchester School , 113-129.

Penrose, E. T. (1995). The theory of the growth of the firm. United States of America: Oxford University Press.

Penrose. (2009). The theory of the growth of the firm (4 ed.). New York, United States of America: Oxford University Press. 
Peric, M., \& Vitezic, V. (2016). Impact of global economic crisis on firm growth. Small business economics, 46(1), 112.

Raheman, A., Qayyum, D. A., \& Afza, D. T. (2014). Efficiency dynamics of sugar industry of Pakistan. Islamabad, Pakistan: Department of Management Sciences-COMSATS Institute of Information Technology Islamabad.

Reilly, F. K., \& Brown, K. C. (2005). Investment analysis and portfolio management (8 ed.). Chula Vista - CA, United States of America: SouthWesternCollege.

Sharma, A., \& Kesner, I. F. (1996). Diversifying entry: Some ex ante explanations for postentry survival and growth. The Academy of Management Journal , 39 (3), 635-677.

Stein, J. (2003). Agency costs, information and capital investment. (M. Harris, \& R. Stulz, Eds.) North Holland: Elsevier, Handbook ofEconomics of Finance.

Toy, N., Stonehill, A., Remmers, L., Wright, R., \& Beekhuisen, T. (1974). A comparitive international study of growth, profitability and risk as determinanats of corporate debt ratios in the manufecturing sector. The Journal of Financial and Quantitative Analysis , 9 (5), 875-886.

Wijewardena, H., \& Tibbits, G. E. (1999). Factors contributing to the growth of small manufacturing firms: data from Australia. Journal of Small Business Management, 37 (2), 88-96. 